Western University

Scholarship@Western

6-1-2018

\title{
Hannah and her Sisters: Theorizing Gender and Leadership Through the Lens of Feminist Phenomenology
}

Rita A. Gardiner Ph.D

The University of Western Ontario, rgardin2@uwo.ca

Follow this and additional works at: https://ir.lib.uwo.ca/edupub

Part of the Education Commons, Feminist, Gender, and Sexuality Studies Commons, and the Leadership Studies Commons

Citation of this paper:

Gardiner, Rita A. Ph.D, "Hannah and her Sisters: Theorizing Gender and Leadership Through the Lens of Feminist Phenomenology" (2018). Education Publications. 174.

https://ir.lib.uwo.ca/edupub/174 


\title{
Hannah and her sisters: Theorizing gender and leadership through the lens of feminist phenomenology
}

\begin{abstract}
This article explores how feminist phenomenology can add conceptual richness to gender and leadership theorizing. Although some leadership scholars engage with phenomenological and existential inquiry, feminist phenomenology receives far less attention. By addressing this critical gap in the scholarship, this article illustrates how feminist phenomenology can enrich gender and leadership scholarship. Specifically, by engaging with the work of four women existential phenomenologists - Hannah Arendt, Simone de Beauvoir, Iris Marion Young, and Sara Ahmed, the rich diversity of phenomenological inquiry is explored. First, Arendt shows the benefits of conceptualizing leadership as collective action, rather than as concentrated in one person, or organization. Second, Simone de Beauvoir highlights how women's situation, and potential, is affected negatively by gender hierarchy. Third, Iris Marion Young builds on Beauvoir's work, exploring how female modality is limited by the social construction of gender. Finally, Sara Ahmed takes phenomenology in a queer direction, showing us how normative ways of thinking about sexuality are limiting to those who do not fit the dominant, familiar pattern. Additionally, in the discussion and concluding sections, the merits and limitations of feminist phenomenology are explored as they relate to gender and leadership theorizing, and suggestions for future research are made.
\end{abstract}

\section{Keywords}

Feminist phenomenology, leadership, gender, embodiment, Arendt, Beauvoir, Young, Ahmed 


\section{Introduction}

Recently, I attended a conference where a young woman described how she felt marginalized in her current role as a union activist. She described her frustration at being ignored by her male colleagues, contrasting her present experience with that of her previous role as a student organizer. What was needed, she argued, was a different kind of leadership within the union environment that was less patriarchal and more welcoming of different perspectives. As I listened, I was drawn back to my own union activism as a young woman, and how I, too, felt silenced. Her words had a palpable effect on me. I felt my face redden, and my heart palpitate, as I remembered similar experiences of being ignored. Three decades, and a continent apart, the effects of this early experience have left an indelible imprint on my body. As I reflected on my own experience, a French expression came to mind, plus ca change plus c'est la meme chose, which roughly translates as the more things change, the more they stay the same. So, too, with women and leadership it seems. In attempting to make sense of continued gender prejudice against "uppity" women, I advocate for feminist phenomenology as one way to further scholarly theory and praxis in gender and leadership.

Hence, in this article, I explore how feminist phenomenology can add conceptual richness to gender and leadership theorizing. I engage with current thinking on feminist phenomenology, as well as discuss insights from four phenomenologists whose work may provide productive avenues of theoretical inquiry for gender and leadership scholars. Although some leadership scholars have engaged with phenomenological inquiry, (Algera \& Lips-Wiersma, 2012; Heil, 2013; Küpers, 2013; Ladkin, 2011, 2013; Lawler, 2005, Lawler \& Ashman, 2011; Ropo, Sauer, \& Salovaara, 2013; Tompkins \& Simpson, 2015) there is far less attention given to the work of feminist phenomenologists (Gardiner, 2015; Pullen \& Vachani, 2013). Thus, this article 
addresses a critical gap in the scholarship, and illustrates the ways in which feminist phenomenology can enrich our theorizing about gender and leadership.

Specifically, by engaging with the work of four women existential phenomenologists Hannah Arendt, Simone de Beauvoir, Iris Marion Young, and Sara Ahmed, I show how their work has much to offer leadership scholars. I concentrate on these specific thinkers because they offer diverse lines of inquiry for rethinking leadership. First, Arendt shows the benefits of conceptualizing leadership as collective action, rather than as concentrated in one person, or organization. Second, Simone de Beauvoir highlights how women's situation, and potential, is affected negatively by gender hierarchy. Third, Iris Marion Young builds on Beauvoir's work, illustrating how gendered embodiment and socialization affects women's lived experiences. Our bodies can tell us things about the world we inhabit; by attending to female modality, Young shows the restrictions imposed upon women by patriarchal thinking. Finally, Sara Ahmed takes phenomenology in a queer direction, showing us how normative ways of thinking about sexuality are limiting to those who do not fit the dominant, familiar pattern. Moreover, Ahmed shows us how racism and sexism are still having negative effects on our organizational, lived reality. With their complementary lines of inquiry, these women writers offer productive avenues for theorizing gender and leadership.

Before turning to their work, I begin with a brief review of the major thinkers in phenomenology and existentialism. Next, I discuss how some leadership scholars engage with phenomenology and existentialism. Then I offer an overview of current thinking in feminist phenomenology. Following which, there is an exploration of the four women theorists previously mentioned. In the discussion and concluding sections, I weave together the disparate threads of 
this discussion, and suggest that engaging with feminist phenomenology may prove a promising avenue for future theorizing on gender and leadership.

\section{Phenomenology: An overview}

Edmund Husserl (1889-1928) is considered to be the founder of phenomenology (Klenke, 2016). A former mathematician, Husserl looks at how logical problems are affected by worldly conditions. One of his aims was to distinguish phenomenology from other forms of scientific investigation. Husserl illustrates the dilemmas that arise from calculative ways of thinking and acting and the ways in which scientific inquiry has disparaged subjective forms of knowledge.

Husserl's main contribution to the field is twofold. First, his notion of lifeworld helps us understand how, as historical beings, we are influenced and limited by our temporal and spatial environment. Second, Husserl's concept of intentionality shows how consciousness is always a consciousness of something (McCann, 1993). Thus, each conscious act is oriented toward something, that is, it must have an object. From a Husserlian perspective "phenomenology provides us with a deeper access to the fullness of phenomena as they present themselves to human consciousness" (Simms \& Stawarska, 2012, p. 9). Husserl's methodological approach places emphasis on describing the things themselves. He (1913) maintains that researchers need to suspend their judgment to allow phenomena to appear as they are. By bracketing off the natural attitude, Husserl argues we can grasp the essence of a phenomenon.

Martin Heidegger (1889-1976), Husserl's student, did not share his ex-professor's belief that it was possible for scholars to bracket off their biases. We all have prejudices, Heidegger maintained; these prejudices influence our perception of the world, and how we engage in research. Contra Husserl, from a Heideggerian perspective it is not possible to bracket off our 
prejudices, since some of these prejudices remain unknown to us. Instead, he insists that our moods affect how we orient ourselves toward things. Furthermore, Heidegger (1977) saw phenomenology as an explanation of the "how" of research, arguing that the "methodological meaning of phenomenological description is interpretation" (p. 86). In conducting a hermeneutic phenomenological inquiry, a researcher must be able to “intuitively" grasp a phenomenon's meaning. For Heidegger, phenomenological inquiry is a way to gain access to ontology, his primary concern. Consequently, Heidegger's interest in fundamental questions, such as what it means to exist, encourages a different way of approaching questions of subjectivity, and the ways in which we live in the world.

Jean-Paul Sartre (1905-1980), an early adopter of Husserl's work, took phenomenology in a different direction, that of existentialism. Sartre's existential phenomenology was a response to the threat posed by Nazism, and recognition that each of us must take responsibility for our actions. His colleague, Maurice Merleau-Ponty (1962) tried to fuse phenomenology and existentialism, arguing that phenomenology is both a philosophy of essences, and a philosophy of existence. In his view, subjectivity is "bound up with that of the body and that of the world" (p. 475). Through the connection between our body and space, we obtain knowledge of the world. That knowledge is not only unique to each of us, because of our specific experiences, but is also fully embodied. And this is why, for Merleau-Ponty, it is vital to attend to our embodied existence in the world, and how this affects our understanding.

Although phenomenology and existentialism share similarities, there are substantial ontological and philosophical differences between the major thinkers. ${ }^{i}$ Additionally, one aspect missing from these accounts is a concern with how gender influences our being-in-the-world. 
Before exploring how feminist phenomenologists have dealt with this lacuna, I examine the different ways in which leadership scholars take up phenomenological and existential inquiry. ${ }^{\text {ii }}$ Leadership scholarship, phenomenological and existential inquiry

As mentioned previously there are leadership scholars who engage with phenomenology and existentialism. Donna Ladkin and Wendell Küper, for example, draw inspiration from Husserl and Merleau-Ponty. Other leadership scholars (Algera \& Lipps-Weirsma, 2011; Heil, 2013; Tompkins \& Simpson, 2015) engage with Heidegger, while others turn to Sartre for inspiration (Lawler, 2005; Lawler \& Ashman, 2012).

One reason scholars use existentialist phenomenology is to critique positivist approaches to leadership. John Lawler (2005), for instance, criticises leadership research that focuses on behavioural dimensions and competencies. Research which tries to identify specific leadership characteristics implies that it has transcendental qualities. But we never see leadership in its entirety; far better to recognize that "leaders make their world and are made by it" (Lawler, 2005, p. 223). Connecting leadership actions with everyday concerns is an important aspect of existential phenomenology. Moreover, rather than focussing on individual leaders, it is important to acknowledge how leadership emerges through relationships. Because, from an existential perspective, each relationship is unique, the quest to find the essence of leadership is likely to fail.

In Rethinking Leadership, Donna Ladkin maintains that phenomenology may help us gain understanding about aspects of leadership often ignored. She argues that Husserl's lifeworld reveals that there are different ways of knowing. As such, we can learn more about leadership if we approach it through different lenses. Considering leadership as it unfolds in the world 
requires us to recognize there are multiple ways to consider what it means to lead. And these multiple perspectives enrich our understanding of leadership.

Exploring leadership through diverse lenses helps us recognize how we are always situated, embodied subjects who are, at one and the same time, perceivers and perceived (Küpers, 2013). Phenomenology inquiry can assist researchers by bringing them "in closer touch with life-worldly practices of leadership" (p. 347). In particular, phenomenology can help us understand leadership by attending closely to relationships (Ladkin, 2013).

Furthermore, by adopting Merleau-Ponty's ideas, Ladkin illustrates how perceptual relationships and the fleshy component of bodies offer us a way to understand employee responses to particular leaders. She maintains that we need to attend to the fleshy nature of leadership since this "felt experience of leadership is important although often overlooked" (p. 322).Using a case study of one leader's affect on others, Ladkin (2013) illustrates how phenomenology is helpful for researchers wishing to obtain a deeper understanding of the relational space that exists between leaders and employees.

Attending to relational space is an important feature for leadership scholars, alerting researchers to how our relationships occur within a spatial world. A phenomenological approach helps us grasp how "places and spaces construct and perform leadership" (Ropo, et al., 2013, p. 378). Because we are affected by different environments in diverse ways, we make "subjective judgements on physical places based on our embodied, sensuous experiences” (p. 379). As leadership emerges in the relationship between "sensing and experiencing bodies" (Ropo et al., p. 380), we may find ourselves feeling uncomfortable in particular organizational spaces without fully recognizing why this unease occurs. By attending to embodied responses, leadership researchers are able to understand how spatial surroundings privilege some bodies while 
marginalizing others. Hence, "the ways in which affect, materiality and leadership connect require space to change the ways in which we think about leadership" (Pullen \& Vachani, 2013, p. 315). Attending to how relationships exist within particular, organizational contexts offers insight into organizational norms that structure our spatial environment, and influence the ways in which some bodies are marginalized while others are privileged.

In this section, I have shown how leadership scholars engage with phenomenological and existential inquiry. In most of these leadership studies, gender is not the central theme. A turn to feminist phenomenology can assist those interested in how a gendered analysis is applicable to phenomenological inquiry. In what follows, I lay out some key aspects of feminist phenomenology.

\section{What is feminist phenomenology?}

Feminist phenomenology is best described as an umbrella term that considers "questions related to gendered experience and sexual difference" (Simms and Stawarska, 2013, p. 6). An important aspect of feminist phenomenology is describing concrete, lived experience. Stoller (forthcoming) argues that there are two historical "moments" that are important to understanding how the discipline emerged. The first moment is usually connected with the publication in 1949 of Simone de Beauvoir's path-breaking study, The Second Sex. The second moment relates to the founding of feminist phenomenology as an academic discipline that took place in Europe and North America in the 1980s. ${ }^{\text {iii }}$

Feminist phenomenology regards experience as "embodied, inter-subjective and contingent, and woven into personal and cultural webs of signification" (Simms and Stawarska, 2013, p. 12). Yet an appeal to individual experience alone is not sufficient to explain a phenomenon in enough depth. This is the reason why many feminist phenomenologists combine 
rich descriptions with an analysis of structural issues, engaging with feminist theory to investigate how ideology, power, and language have an effect on lived experience. This recognition encourages us to attend to individual accounts but also to comprehend phenomena in broader ways. Additionally, a complexity of experiences and viewpoints enables a richer, phenomenological understanding. Such an understanding requires us to pay attention not only to what is said, but what is left unspoken. In regards to leadership scholarship, for example, we might wonder why scholars who engage with phenomenology rarely focus their attention on gender issues.

In this section, I have provided an overview of howfeminist phenomenologists have enhanced phenomenology by bringing a gendered perspective to phenomenological and existential writings. A central strength of feminist phenomenology is its openness to interdisciplinary perspectives and new ways of thinking (Stoller, forthcoming). Topics range from neuroscience to art, sport, film, queer identity, masculinity studies, as well as racial and gendered embodiment. In short, feminist phenomenology is an approach in which phenomenological inquiry and feminist theory inter-relate in multiple ways. As Ladkin (2013) encourages leadership scholars to engage with phenomenology as a methodology so, too, can its feminist counterpart offer valuable insight, useful to gender and leadership scholarship.

Next, I turn to discuss the four theorists mentioned in the introduction to illustrate how each theorist offers us a different approach to phenomenological and existential inquiry. I begin with Hannah Arendt.

\section{Hannah Arendt (1906-1975)}

Hannah Arendt's work is steeped in the phenomenological tradition, but she has a very specific approach to the topic. Trying to categorize Arendt's writing is difficult, since her work is 
so wide-ranging. In a comment to a student Arendt stated that she viewed herself as a kind of phenomenologist, but not in the same way as Husserl and Heidegger (Young-Bruel, 1982). Arendt's work is inspired not only by phenomenological inquiry, but also influenced by Immanuel Kant, as well as critical theorists like Walter Benjamin, a great friend of hers. Through Benjamin, Arendt learned the importance of "pearl diving," that is, looking to historical accounts to find the hidden gems that can help us find meaning in our lives. A German-born Jew, the events of the Second World War, specifically the Holocaust, was an ongoing theme in her writing, as she tried to understand why such atrocities occurred.

In her first major work, Origins of Totalitarianism, Arendt maintains that lying is the key characteristic of totalitarian regimes. In these regimes, politics becomes "a game of cheating" (p. 382), whereby leaders give out statements one day, which they then refute on another. Facts do not matter, it seems, because the leader is always right. A chief goal of totalitarian regimes, she argues, is to dismantle governing structures. These structures are regarded as barriers to their future aim which, in the case of the Nazis, was world-domination. For Arendt there is a profound distinction between tyrannical and totalitarian regimes. In her view, the authoritarian dictator differs from the totalitarian leader in that the former wants to restrict people's freedom whereas the latter wants to abolish freedom altogether. The tyrant is not necessarily ideologicallymotivated; neither does he have a grand vision, as in the case of a totalitarian enterprise.

Arendt argues that the essence of totalitarianism is terror. And that terror emerges as fear of the Other. Fear contributes to confusion on the part of the populace, and the Nazi regime itself. For example, so as to keep control the Fuehrer's orders given are vague. People are told that they must "execute the will of the leadership" (Arendt, 1951, p. 400) but what that "willing" consists of constantly changes, since this help create confusion. What is more, within a 
totalitarian system, the Leader's actions contradict what they say. This is no accident, as the Leader gains further control through confusing others by their contradictory statements.

In other work, Arendt $(1958,1971)$ traces the totalitarian tendencies in philosophical thought, and connects it to solipsistic thinking. She regards this tendency for philosophers to be solipsistic as a result of philosophers' retreat from the public world into the private world of ideas. In Arendt's view, much classical philosophical thought privileges self over others. This solipsistic approach can be dangerous, especially as it relates to philosophical conceptions of leadership, which, since Plato, have focussed on the singular leader, rather than a more relational way of thinking about leadership. Arendt regarded this distinction between leader and led as dangerous, since it encouraged hierarchical ways of thinking. For Arendt, this solipsistic approach to leadership led to the emergence of totalitarian modes of ruling. This type of sovereign rule is not leadership as Arendt perceives it, but rather a type of mastery.

Thinking about leadership as mastery is predicated on the self-made man (or woman) who has the strength, vision, and capacity to lead others, because of their mastery of the self. But Arendt (1958) maintains leadership understood as mastery undermines collective freedom. As such, this way of thinking and being is negative to human flourishing, understood as the freedom for all to engage openly in dialogue and debate.

In The Human Condition, Arendt provides us with a fascinating account of leadership as collective action. She argues leadership functions best when it arises out of individuals working together over common cause, since they discover the strength of collective action. As such, it is the actions that emerge when a group of committed individuals work together toward a common goal that constitutes a robust sense of leadership. Yet, over time, leadership understood as 
collective action, has been erased. Now it is the leader as sovereign individual that dominates our thinking.

Arendt (1958) is also interested in how narrative is fundamental to understanding how we live in the world as distinct individuals in a plural environment. Each person's individual uniqueness unfolds within the interwoven fabric of life that Arendt refers to as "the web of relationships" (p. 183). Her relational approach to leadership offers us a richer understanding of human togetherness. However, Arendt is less insightful when it comes to the topic of women leaders. In response to an interview question, she (1994) replied "It just doesn't look good when a woman gives orders. She should try not to get into such a situation if she wants to remain feminine" (p. 3). Arendt's comments highlight a seemingly ageless debate between those women who perceive themselves as feminists, and those who prefer to hold on to their "feminine" advantages. Yet it is noteworthy that Arendt followed up her comment by saying that she had always done exactly as she chose.

Although Arendt may sound something of a contrarian, her work offers valuable insights into leadership, especially in relation to collective action and freedom. In addition, her political insights into totalitarian ways of thinking and acting illustrate the dangers for human freedom when leaders have too much control over others. As such, her thinking is still pertinent today. That said, Arendt's seeming lack of interest in gendered ways of being is in sharp contrast to the next theorist I discuss.

Simone de Beauvoir (1908-1996)

For most of her life, Simone de Beauvoir was reluctant to use the term "feminist," seeing its Anglo-American roots in contradiction to her existential standpoint. ${ }^{\text {iv }}$ Only in the 1970s did 
Beauvoir change her negative stance toward feminism (Kruks, 2013). Revisiting Beauvoir's oeuvre can add a conceptual richness to work in gender and leadership, not least because she shows how women's lives have often been regarded as less "valuable" than their male counterparts. The historical legacy of gender inequality bears a significant trace in our social imagination, thus influencing our thinking about leadership.

Alongside Jean-Paul Sartre and Maurice Merleau-Ponty, Beauvoir played an important role in rethinking philosophy through an existential lens, informed by Husserl and phenomenology and that of Hegelian philosophy. In The Second Sex, first published in France in 1949, she traces what it means to be a woman through mythological, historical, psychological, and sociological aspects. Beauvoir adapts Merleau Ponty's concept of the phenomenal body to describe women's experiences (Stoller, forthcoming). She pursues the theme of gender constraints, arguing that freedom is at odds with marriage and the family. Conservative family values, Beauvoir states, work to restrict women's lives, as they are taught to put family before self which, in turn, limits their sense of possibility.

Although Merleau-Ponty $(1962,2007)$ argues that we always live in the world as embodied subjects, Beauvoir contends his analysis ignores gender in favour of a neutral body subject. In contrast, she focuses on women's lived experience, which Beauvoir examines from various vantage points. In so doing, she illustrates how people's ability to act is constrained by their gender, age, sexuality, and race. Furthermore, her trenchant critique of women's roles in society, and her discussion of oppression are helpful to obtaining a broader understanding of systematic inequity as it relates to leadership. Although Beauvoir's work has been criticized for taking bourgeois white women as the norm, this criticism ignores how it is particular situated, gendered and embodied experiences that were her main concern. 
Further, Beauvoir's work is not only valuable because of her detailed analysis of women's lived experience; her writing also offers insights into racism. In describing her experiences in America, for example, Beauvoir shows how African Americans were treated as objects of disdain by white people. In one instance, travelling on a bus in the American South, Beauvoir witnessed a heavily pregnant African-American woman in severe distress because of the heat. Yet no-one would offer this woman a seat on the bus. Beauvoir comes to the realization that if she offered up her seat to this woman, as she wanted to do, this gesture could make the situation dangerous for both of them. Contra Sartre, her example illustrates that we cannot always act as we choose, because this ignores our place in the social hierarchy.

Not everyone is able to transcend their circumstances, therefore, Beauvoir (1948) argues we must not conceive of freedom in an abstract way, but consider the concrete conditions that cause oppression and resistance to it. Only then will we be able to develop strategies to help move beyond oppressive social systems such as racism and sexism. Beauvoir maintains it is our ethical imperative to will the freedom for others by striving to eradicate injustice. As she states in The Ethics of Ambiguity "the cause of freedom is not that of others more than it is mine: it is universally human" (p. 48). Although freedom is supposedly "universally human," the situation is somewhat different when we look at people's concrete experience.

For Beauvoir (2014), each individual's ability to succeed is affected by their gender, and gender prejudice is deeply engrained in Western society. Echoing Arendt, she observes that “[N]either man not woman like working under a woman's orders (p. 739). In effect, what this means is that women leaders will probably have to work much harder to obtain people's confidence. Often, employees regard women leaders with suspicion, as Beauvoir notes, "at the outset she is suspect; she has to prove herself" (p. 739). In addition, male and female leaders are 
perceived differently: "[T]he man is used to being imposing; his clients believe in his competence; he can let himself go; he is sure to impress. The woman does not inspire the same feeling of security in others" (p. 740). Because of our traditional ways of connecting leadership with masculinity, it is more difficult for women to be accepted in a leadership role. Moreover, gender hierarchies affect our sense of self such that in order to be regarded as accomplished “today's woman needs above all forgetfulness of self: but to forget oneself one must first be solidly sure that one has already found oneself" (p. 740). Beauvoir seems to suggest that the public demands of leadership are more difficult for women who have been socialized as carers, rather than as leaders within the public realm.

Additionally, Beauvoir illustrates how women's freedom from their situation as Other can only be achieved through collective liberation. Such liberation "demands above all that the economic evolution of the feminine condition be accomplished" (p. 664). As she states "[w]hat is beyond doubt is that until now women's possibilities have been stifled and lot to humanity" (p. 751). It is, therefore, in society's interest that women are perceived as men's peers, but this requires that women are afforded the same respect, and offered the same opportunities as their male counterparts. In short, for women to succeed within organizational life the future needs to be radically different from the past.

Beauvoir's theoretical framework can also help women understand how the conflicts they may have in the workplace because of their gender (Wallace, 2009). For example, when women take on male character traits so as to be successful in a male-dominated profession what can happen is that women lose a sense of self, and find themselves becoming inauthentic in their actions. But they may also be seen as performing badly, contradicting their gendered role (Mavin, Grandy, and Williams, 2014). Such a paradoxical situation is difficult to overcome. 
Finally, thinking with Beauvoir helps us to see how particular circumstances and structural conditions affect women's agency, a topic of interest to Iris Marion Young, to whom I now turn.

Iris Marion Young (1949-2006)

Iris Marion Young was a committed feminist, and social activist. Influenced by Beauvoir, she explores female embodiment through her essays on pregnancy, menstruation, and questions of home and belonging. Her most famous essay on female embodiment is "Throwing like a Girl." Here, Young (1990) argues that "human existence is defined by its situation (p. 142). In keeping with Beauvoir, she views women's situation as located in "a given sociological and historical set of circumstances, despite individual variation in women's experience, opportunities and possibilities, has a unity that can be described and made intelligible" (p. 142).

Young (1990) maintains that male phenomenologists have not paid enough attention to the specificity of women's lives. She critiques Merleau-Ponty, for instance, $(1962 ; 2007)$ for taking the male body as the norm. Although she agrees that our subjective understanding of the world results from how the body is oriented towards things, nonetheless, she argues there is a contradiction between women's lived experience and their ability to transcend their situation, because of patriarchal limitations that are imposed upon them. These limitations affect bodily comportment, motility, and spatiality. Indeed, for women, there is a lived tension "transcendence and immanence, between subjectivity and being a mere object" (Young, 1990, p. 144). Some women fail to put "their whole bodies into engagement in a physical task with the same ease and naturalness as men" (p. 145). As a result, women do not trust their bodies as men do theirs, and 
this lack of trust means that some women tend to underestimate their achievements, and their potential.

One reason for this underestimation of a young woman's talents is a result of a girl's social conditioning. As a girl grows up, she is encouraged to view herself as fragile. But seeing oneself as fragile may negatively affect a young woman's ability to act in a confident manner. Conversely, whenever a woman opens "her body in free, active, open extension and bold outward directedness" this invites sexual objectification (p. 155). In turn, this objectification further limits women's action, and their belief in their own potential.

Although Merleau-Ponty describes the lived body as "pure fluid action," Young contends this is not how most women encounter the world. Instead of an open intentionality, women exhibit what Young describes as an "inhibited intentionality," whereby the "I can" too often becomes the "I cannot" (p. 148). Hence, women's lived experience shows that Merleau-Ponty's unity of body and world is a contradiction, which derives from how women's bodies are often objectified by others, and even themselves. As a result, "she remains rooted in immanence, is inhibited and retains a distance from her body as transcending movement and from engaging in the world's possibilities" (Young, 1990, p. 153).

In regards to leadership, Young argues that this mistrust of our bodies may be a reason why many women doubt their leadership abilities. She writes: "I have an intuition that the general lack of confidence that we frequently have about our cognitive or leadership abilities is traceable in part to an original doubt of our body's capacity (Young, 1990, p. 156). If she is right then it seems important to recognize how gendered embodiment influences our leadership potential. 
Two decades after first publishing "Throwing like a girl," Young revised her views on female modality, acknowledging her daughter's generation had opportunities and confidence in their abilities that her own generation lacked. But Young reaffirmed her argument about the connection between the materiality of gendered embodiment and inequality. Similar to Beauvoir, she argued our situation, both present and past, influences women's ability to transcend normative ways of thinking about gender roles. Thus, her work can help us understand why many women fail to achieve their potential.

In this section, I have concentrated on Young's work on female embodiment. Her focus on female modality enriches the work of Merleau-Ponty, because of her emphasis on the gendered aspect of bodily interaction. Young's work offers insight into gendered embodiment, but also into structural injustice. One of Young's strengths is to bring feminist theory and phenomenological inquiry into dialogue so as to examine the continuance of gender inequities on an individual, societal, and global scale. She (2011) argues we need to consider how "social structural processes" enable some bodies to flourish while constraining others. Other social structures we encounter on a daily basis, such as rules or laws, appear neutral. Yet this seeming neutrality is erroneous for these social structures produce and reproduce gender inequities, and are a causal factor in continued injustice. Young maintains that we must be willing to call organizations to account for continued injustices. This is exactly the kind of accounting that our next theorist is interested in pursuing.

\section{Sara Ahmed (1969-)}

Sara Ahmed is a queer theorist, critical race scholar, and feminist phenomenologist. Here, I focus on her work on queer phenomenology and her writing on the problems with discourses of 
diversity. Although some theorists argue that Ahmed brings a postructuralist perspective to phenomenology (Bergreen, 2014), Ahmed (2014) argues that hers is a "practical" phenomenology.

In Queer Phenomenology, Ahmed adopts Husserlian ideas to show that it is not just how we orientate ourselves to objects that matters, but also that when we focus on a particular object, other objects recede into the background. When bodies are comfortable in their spatial orientation, they will be more likely to act in particular ways. Ahmed argues that we are always occupied by different things. For example, we have an occupation, but we also are occupied by our thoughts. When we are occupied with one thing, we fail to occupy ourselves with another. Ahmed points out how time is taken away from our projects in different ways. As an example, she shows how, in Ideas, Husserl focuses on his writing desk, a key piece of equipment for a writer. He imagines what he cannot see; in this case, his children playing in the summerhouse. What Husserl does not imagine is the kitchen, since the domestic sphere is unimportant to him. As with many male philosophers, his needs and wants are cared for by others. Such care enables him to direct his attention to his writing, and to be comfortable doing so.

Ahmed contrasts Husserl's experience with that of the poet, Audre Lorde. Lorde describes how her desire to write was thwarted by her children. Each time she tries to orientate herself to her writing, little fingers start tapping on Lorde's typewriter, willing her away from her writerly occupation, and back into their lives. We focus on what matters to us; the problem is that, for many women, what matters is often in conflict, as a result of familial responsibilities.

Because of the challenges of reconciling personal and career priorities, this may, in turn, limit some women's desire to take on leadership roles. That is, they take themselves out of the running for top jobs, because of the difficulties in bridging multiple responsibilities. The key 
point is that prescribed gender roles not only influence our ability to occupy ourselves with what matters, that which matters to us may well be in conflict. And this conflict will have an effect on not only what we can do, but what we are willing and able to do given the situation. Gender matters because our lived environment is structured in such a way that women still bear the greatest responsibility for family affairs, and this state of affairs puts additional pressure on what a body is able to do in the public sphere.

We saw earlier that dominant social norms may negatively affect people's ease of movement within particular surroundings (Ropo et al., 2013). Similarly, Ahmed shows us how our spatial surroundings are never neutral, and this is why it is necessary to queer our lived environment. Ahmed (2006) argues a queer phenomenology can help us further understand how space is never neutral. Space is never empty but full of past gestures, assumptions, and intentions. Taking Merleau-Ponty’s work in new directions, Ahmed (2006) argues that "heterosexuality functions as a background" (p. 87). What this means is that bodies take on "shape of norms that are repeated over time and with force." (p. 91). Thus, our bodies sediment their histories; we are influenced by our past experiences, which leave a bodily imprint. Furthermore, historical sedimentation not only has an impact on the present, it also has a future impact on what bodies can do. Queering spaces can open up our understanding of different modes of being-in-the-world. Structural limitations work on the body in a visible way, but we are also habituated into modes of being. These normative ways of thinking become imprinted on our bodies through institutional practices.

In terms of gender and leadership, we could argue that normative practices affect how we orientate ourselves to our spatial surroundings. Who feels "at home" in one surrounding may feel discomfort in another. When we feel uneasy, this influences how we move through space. For 
those who feel marginalized, there is a double bind in that we are not only silenced by the discomfort we feel, we silence ourselves. Sometimes, silencing can be a gesture of defiance but, at other times, silencing is an expression of marginalization from the dominant norms.

In trying to understand why marginalization flourishes in many institutional contexts, Ahmed (2007) explores how the discourse of diversity is used in universities. Because diversity management connects with neoliberalism, she argues it poses little threat to institutional norms. Rather the discourse of diversity enables universities to enhance their international profile. Diversity has a dual role, to promote the institution, and to attract people to it. In so doing, “diversity becomes an instrument or technique" (p. 244), allowing administrators to promote particular, idealized images of universities. Hence, "diversity" discourse serves to bolster organizational ideals, rather than question ongoing inequities in organizational practices.

The paradox is that, in many organizations, racism and sexism (as well as other forms of inequality) continues to flourish. If we do not account for how institutional discourses fail to deal with inequalities, it will be difficult to foster systemic change. Ahmed's resignation from the university she worked at, because of what she saw as a failure to address gender and racial inequities is indicative of a certain frustration at the neoliberal university. What it shows us that being willing to fight against social inequity comes at a personal cost. Although her action illustrates leadership, it is not the kind of public gesture that most of us choose. Yet if we are not willing to fight for organizational change, then the prospects for radical change in organizations seem extremely dim.

\section{Discussion}

This special issue on gender and leadership calls for papers that "stimulate new conceptual thinking" (Leitch \& Stead, 2015). My aim has been to show how feminist 
phenomenology can add a conceptual richness to debates in gender and leadership. I am not suggesting that this is the only theoretical framework to adopt. However, I am suggesting that we can benefit from the depth of thinking that phenomenological theory offers. Whether it is prejudice, power, or gendered practices in the workplace, employing a feminist phenomenological lens can help us obtain insight into the theory and praxis of leadership.

The four thinkers I concentrate on here offer diverse approaches to phenomenological inquiry. Their diverse approach to phenomenological inquiry is a strength challenging us to consider issues related to gender and leadership from a multiplicity of perspectives. As such, they can help researchers think more deeply about the interconnections among gendered embodiment, intersubjective relationships, and structural inequities that pervade leadership theory and praxis. Each of these topics is valuable to an overall comprehension of how individual, structural, and systemic prejudice against women leaders operates. As importantly, these thinkers can offer insight that may help feminist scholars challenge the ongoing "dominant, masculinised frameworks and powers structure underpinning leadership research" (Leitch \& Stead, 2015, p. 126).

Additionally, phenomenology helps us understand how space, both physical and intellectual, serves to produce and reproduce particular leadership bodies. Bringing these ideas together may help to forge new paths for gender and leadership research. Attending to our embodied experiences in the world, for example, helps us understand how leadership is configured very differently if we focus on the body of the CEO rather than the processes and practices of academics engaged in leadership research (Kelly, 2014). That said it is not only in specific environments that can make some bodies feel out of place, scholarly disciplines can also have this effect (Biersma, 2017). Laura Biersma (2017) explores how "[leadership literature is 
dominated by ideal images of leaders...individuals who operate within a culture and value-free space" (p. x). There are no value-free spaces; our spatial surroundings are imbued with past interactions.

These interactions illuminate the stickiness of gender stereotypes, and the ways in which the social imagination holds on to particular modes of thinking and engaging with others. Such engagement indicates the ways in which gender hierarchy and power imbalances continue to operate within the organizational world and beyond. These gendered, power imbalances are produced and reproduced in organizations, society, and material practices. To take but one example, in the case of women leaders, there is a greater focus on their appearance than their male counterparts (Mavin \& Grady, 2012). Amanda Sinclair (2013) claims that women leaders' bodies are seen as an indication of their moral worthiness. Irrelevant issues, such as being overweight, visible grey hair or poor dress sense, may have an inverse effect on a woman leader's perceived effectiveness. Consequently, how we assess a leader's performance is sometimes judged, not on their actions, but on their "leaderly" appearance.

Hence, we need to consider how gendered practices reinforce cultural assumptions about "masculinity" and "femininity" by interrogating "the dominant masculinised frameworks and power structures underpinning leadership research" (Leitch \& Stead, 2015, p. 126). To do so, we must comprehend the deep structures that underpin our thinking about leadership, and societal attitudes toward gender norms. Feminist phenomenology offers one theoretical approach to help us understand how gender hierarchies and power imbalances operate on a micro and macro level.

There is no one way, or right way, to "do" feminist phenomenology. Rather, phenomenology is, as Merleau-Ponty (2007) once remarked, "a manner or style of thinking" (p. viii) that offers multiple possibilities and divergent theoretical paths. Such a mode of inquiry has 
the potential to offer new opportunities for research in gender and leadership theory. For example, feminist phenomenology can help us understand how gendered practices influences leadership by examining how organizational micro practices not only affect our everyday life but also leave an imprint on the body. Gender bias works to negatively influence women's perceptions of themselves as leaders. Feminist phenomenology can assist us in comprehending some of the underlying structural issues that concern us.

What we need is a troubling of organizational structures, and dominant forms of privilege (Blackmore, 2014). So it may not be enough to hire women as leaders if the desired outcome is gender justice. Not all women are good leaders, or pleasant to others, as Mavin, Grandy, and Williams (2014) have shown. Women hold other women accountable to normative gendered expectations, thus perpetuating gender stereotyping (p. 447). Furthermore, micro-aggressive acts such as denigrating the appearance of other women, or denying them advancement opportunities perpetuate the gender imbalance in leadership. What this suggests is that placing some women in powerful positions will not lead to the empowerment of women as a group (Kellerman and Rhode, 2007). And this is why gender and leaders scholars must pay attention to other forms of inequity in addition to gender.

As such, an attention to the intersections of identity offers us a wider perspective for understanding structural inequities. Specifically, Ahmed's work can help us understand how intolerance is masked by policies, which suggest an inclusive workplace but do little to change systemic racism and sexism. Further, the work of Iris Marion Young helps us understand how micro-aggression acts, over time, leave a bodily imprint that negates women's confidence.

Jan Shaw (2010) maintains the materiality of leaders' bodies is often ignored by leadership scholars. As such, 'leadership scholarship has contributed to the selective invisibility 
of some gendered bodies' (Sinclair, 2013, p. 249). Using the work of Beauvoir and Young can help us understand how the materiality of our interactions within the world influences our thinking about leadership.

We must understand how social, historical, and cultural attitudes affect leadership. Here, Arendt's work is instructive. She looks to the foundation of our distinction between the leader and others, illustrating how there is a fundamental chasm between those who lead and the rest of us. Moreover, she shows how our understanding of leadership is profoundly gendered (Gardiner \& Fulfer, 2017). Attending to lived reality past and present can offer us more depth in our leadership inquiries.

A decade ago, Höpfl and Matilal (2007) argued that "unlike gender studies in general, there has been little attempt to provide a serious and systematic study of women's leadership" (p. 202). This special issue is one of many recent publications that is designed to move the conversation on gender and leadership forward (Elliot \& Stead, 2007; Harding, Ford \& Fotalki; 2013; Gardiner, 2015; Kellerman \& Rhode, 2007; Madsen, 2017). Further, as Julia StorbergWalker and Paige Haber-Curran (2017) recognize we need insights and contributions from multiple theoretical perspectives if we are to enrich current theorizing on gender and leadership. My aim has been to argue that feminist phenomenology is a productive way to deepen our understanding of gender and leadership. Gender analysis, as Raewyn Connell and Rebecca Pearse (2017) contend, requires the work of many hands. Moreover, "it is the business of theory to think beyond what appears to be given, to dig through the myths and grapple with the inequalities" (p. 152). Feminist phenomenology can help us understand the perpetuation of myths and inequalities that speak to the everyday, embodied realities of our gendered lives. 
The majority of work published in gender and leadership concentrates on organizational frameworks. By focusing on these organizational aspects, we give short shrift to other forms of leadership. Is it not time to broaden our discussions, and take account of leadership outside organizational boundaries? More research on social activism, volunteer activity, and caring for family and neighbours could enrich gender and leadership discussions. In short, we need to think about leadership-in-the-world from multiple vantage points (Gardiner, forthcoming.)

Similarly, we need different theoretical approaches to leaders, and leadership, in diverse spaces. Feminist phenomenology is one approach that has much to offer gender and leadership theorists. In examining how leadership scholars take up phenomenology, it is clear that the work of feminist phenomenologists is often ignored, a critical gap in current leadership scholarship that this article sought to address.

Turning to the limitations of this inquiry. One limitation is that I have only been able to touch upon each thinker's work. Thus, one could equate this encounter with feminist phenomenology as more like a first date than a steady relationship. My aim was to introduce some readers to this field of inquiry, and reacquaint those who may know these authors, but have not considered using them in their own leadership research. I recognize that this discussion is but a starting point.

A second limitation may be related to the concept of essentialism. Thinking about essentialism has been a scholarly sin for many decades now. Yet the writers I examine do not subscribe to essentialist ways of thinking about subjectivity. Rather, they are conscious of how gender relations affect subjectivity, spatiality, and temporality. That said, we can learn a great deal from lived experience, without making assumptions that such experience is universal. Indeed, Johanna Oksala (2011) argues that poststructuralists and phenomenologists could gain 
from a more robust understanding of each other's approach. Just as organizational theorists

(Fotaki, Metcalfe, \& Harding, 2014; Mavin \& Grandy, 2013; Ford, Harding, \& Learmouth, 2008) show how feminist postructuralist theory can enrich discussions in organizational study so can phenomenological inquiry enrich gender and leadership. In any event, what is needed, as Oksala notes, are philosophically sophisticated understandings that recognize how our subjective experience is always situated, embodied, and gendered.

\section{Future directions and concluding remarks}

Turning to possibilities for future research, temporality is one under-researched area in gender and leadership theorizing. A phenomenological approach to temporality could add valuable insight into discussions on gender and leadership. Much is gained from considering the ways in spatial surroundings affect our understanding of leadership. Similar gains can emerge through a richer understanding of time. For example, how do our memories influence our theoretical understanding of what it means to be a leader? Or what do our recollections of leadership moments teach us about what matters to us? Although leadership scholars are engaging with phenomenological discourse to understand the felt bodily experience, temporality is an under developed theme in leadership research. To understand how some women become leaders but also how most women do not, thinking about how memory affects leadership choices could be a productive enterprise.

I want to close by returning to the vignette I introduced at the beginning of this article, and engaging in a kind of thought experience. Just to recap, I was expressing similarities between my own experiences and those of a young woman who was discussing the need for a fundamental change in leadership in unions. How might the four women theorists I have 
discussed perceive my tale? First, my sense is that Arendt would concentrate on the need to share stories. Rather than sitting with my memories, she would encourage us to speak out in order to share experiences so as to change the future. Beauvoir might argue that this vignette serves to illustrate that gender is still a major issue in organizations such that even those that profess equality do so within a hierarchical model. By contrast, Young might suggest in recalling those embodied aspects of the experience, I acknowledge that although similarities exist between the two narratives, our experiences are not the same. Finally, Ahmed might encourage me to develop a relationship with this young woman, and share our experiences through a blog, or other social media site that would encourage others to share their stories. Only by sharing our narratives can we begin the task of rethinking our collective future.

In “A feminist phenomenology manifesto," Helen A. Fielding (in press) argues we must begin to imagine different possibilities for future selves. These possibilities must emerge from the theorizing we engage with now. This means engaging in brave conversations about social and political transformation. Otherwise, “women's future selves may not be radically different than women's past selves" (Fielding, in press, nd.).

Engaging with feminist phenomenology can help us engage in new conversations that help us conceive of new possibilities for gender and leadership research. I see this as the start of a conversation between feminist phenomenology and theorists engaged in gender and leadership research. It is my sincere hope that others will join me in this conversation. For there is much work left for us to do. 


\section{References}

Ahmed, S (2006) Queer phenomenology: Orientations, objects, others. Durham, NC and London: Duke University Press.

Ahmed, S (2007) The language of diversity. Ethnic and Racial Studies 30(2): 235-256.

Ahmed, S (2012) Whiteness and the general will: Diversity work as wilful work. PhiloSOPHIA 2(1):1-20. DOI: 10.1353/phi.202.0001

Ahmed, S (2014) Practical phenomenology. In: Feminist Killjoys. Available at https://feministkilljoys.com/2014/06/04/practical-phenomenology/

Algera, P \& Lips-Wiersma (2012). Co-creating the conditions under which all members of the organization can be authentic. The Leadership Quarterly 23: 118-131. DOI:10.1016/j.leaqua.2011.11.010

Arendt, Hannah. The origins of totalitarianism. New York: Harcourt, Brace and Company, 1951.

—. The human condition. Chicago: University of Chicago Press, 1958.

- The life of the mind. Edited by Mary McCarthy. New York: Harcourt, Brace and Jovanich, 1978.

Berggren, K (2014) Sticky masculinity: Post-structuralism, phenomenology and subjectivity in critical studies on men. Men and Masculinities 17(3): 231-252.

Blackmore, J (2013) A feminist critical perspective on educational leadership. International Journal of Leadership in Education, 16(2): 139-154.

DOI: $10.1080 / 12603124.2012 .754057$

Biersma, L (2017) Foreword. In Storberg-Walker, J and Haber-Curran, P (eds) Theorizing Women and Leadership: New insights and contributions from multiple perspectives. Charlotte, NC: Information Age Publishing, pp. vii-xii. 
Butler, J (Dec., 1988) Performative acts and gender constitution: an essay in phenomenology and feminist theory. Theatre Journal. 40(4): 519-531.

Connell, R W and Pearse, R (2017) Gender: In world perspective. Third edition. London: Polity Press.

Calcagno, A (2007) The philosophy of Edith Stein. Pittsburg: Duquesne University Press.

De Beauvoir S (1948) The Ethics of Ambiguity. New York: Citadel Press.

De Beauvoir S (2013) The Second Sex. Trans. C Borde and S Malovany-Chevalier with an introduction by J Thurman. New York: Alfred A. Knopf.

Eagly, A H and Heilman, M E (2016) Gender and leadership: Introduction to the special issue, The Leadership Quarterly 27(3): 349-353. DOI: 10.1016/J/LEAQUA.2016.04.002

Fielding H A (Forthcoming) A feminist phenomenology manifesto. In Fielding, H A and

Olkowski, D E (In Press) Feminist Phenomenology Futures. Indiana: Indiana University Press.

Fotaki, M, Metcalfe, B D, and Harding, N (2014) Writing materiality into management and organization studies through and with Luce Irigaray. Human Relations 657(10): 12391263. DOI: $10.1177 / 0018726713517727$

Gardiner, R (Forthcoming) Leadership-in-the world through an Arendtian lens. In Fielding, H A and Olkowski, D E (In Press) Feminist Phenomenology Futures. Indiana: Indiana University Press.

Gardiner, R (2015) Gender, authenticity and leadership: Thinking with Arendt. London and New York: Palgrave MacMillan. 
Heil, D (2013) Viewpoint: what 'selves' is authentic leadership true to? A Heideggerian contribution. In Ladkin, D \& Spiller, C (2012). Authentic leadership: Clashes and converges. Cheltenham, UK: Edward Elgar, (pp 69-71).

Heinämaa, S and Rodemeyer L (2010) Introduction. Continental Philosophy Review 43: 1-11.

Höpfl, H and Matilal S (2007) "The lady vanishes:” some thoughts on women and leadership. Journal of Organizational Change 20(2): 198-208.

Kellerman, B and Rhode, D (Eds.) (2007) Women and leadership: The state of play and strategies for change. New York: Wiley.

Kelly, S (2014). Towards a negative ontology of leadership. Human Relations 67(8): 905-922. DOI: $10.1177 / 0018726713503177$.

Klenke, K (2015) Qualitative research in the study of leadership. Second edition. Bingley, UK: Emerald Group Publishing Limited.

Kruks, S (2012) Simone de Beauvoir and the politics of ambiguity. Oxford: Oxford University Press.

Küpers, W (2013) Embodied inter-practices of leadership - Phenomenological perspectives on relational and responsive leading and following. Leadership 9(3) 335-357. DOI: $10.1177 / 1742715013485852$

Ladkin, D (2010). Rethinking leadership: A new look at old leadership questions. Cheltenham, UK: Edward Elgar.

Ladkin, D (2013). From perception to flesh: A phenomenological account of the felt experience of leadership. Leadership 9(3): 320-334. DOI: 10.1177/1742715013485854

Lawler, J (2005). The essence of leadership? Existentialism and leadership. Leadership 1(2): 215-231. DOI: $10.1177 / 1742715005051860$ 
Lawler, J and Ashman, (2012) Theorizing leadership authenticity: A Sartrean perspective. Leadership. 8(4): 327-344. DOI: 10.1177/1742715012444685

Leitch C and Steadman V (2015). Special issue of Leadership: Gender and leadership. Leadership 11(1): 126-127.

Mavin, S, Grandy, G, and Williams, J (2014) Experiences of women elite leaders doing gender: Intra-gender micro-violence between women. British Journal of Management 25: 439455. DOI: $10.1111 / 1467-8551.12057$

Mavin, S and Grandy, G (2013). Doing gender well and differently in management. Gender in Management: An International Journal 27(4): 218-231.

McCann, C (1993) Four phenomenological philosophers: Husserl, Heidegger, Sartre, MerleauPonty. London \& New York: Routledge.

Merleau-Ponty, M (1962) The visible and the invisible. Edited by Claude Lefort and translated by Alphonso Lingis. Evanston: Northwestern University Press.

Merleau-Ponty, M (2007) The phenomenology of perception. Translated by Colin Smith. London \& New York: Routledge Classics.

Oksala, J (2011) Sexual Experience: Foucault, phenomenology, and feminist theory. Hypatia 26(1): 207: 223. DOI: 10.1111/j.1527-2001.2010.01153.x

Pullen, A and Vachhani, S (2013). The materiality of leadership. Leadership 9(3): 315-319. DOI: $10.1177 / 1742715013485852$

Ropo, A, Sauer, E and Salovaara, P (2013) Embodiment of leadership through material place. Leadership, 9(3): 378-395. DOI: 10.1177/1742715013485858

Simms, E M and Stawarska, B (2011) Introduction: Concepts and methods in interdisciplinary feminist phenomenology. Janus Head, 6-16. 
Stead, V (2014) The gendered power relations of action learning: a critical analysis of women's reflections on a leadership development programme. Human Resource Development International, 17(4): 416-437.DOI:10.1080/13678868.2014.928137

Stoller, S (In press) What is feminist phenomenology? Looking backwards and into the future. In Fielding, H A and Olkowski, D E (In Press) Feminist Phenomenology Futures. Indiana: Indiana University Press.

Storberg-Walker, J and Haber-Curran, P, (Eds.) (2017) Theorizing women and leadership: New insights and contributions from multiple perspectives. Charlotte, NC: Information Age Publishing.

Tomkins, L and Simpson, P (2015) Caring Leadership: A Heideggerian perspective. Organization Studies 36(8), 1013-1031. DOI:10.1177/0170840615580008

Young, I M (1998) Throwing like a Girl: Twenty Years Later. In Welton, D (ed) Body and Flesh: A Philosophical Reader. Malden, MA and Oxford: Blackwell Publishers Inc, pp. 286-291.

Young, I M (2005) On Female Body Experience: "Throwing Like A Girl” and Other Essays. Oxford: Oxford University Press.

Wallace, P (2009) Career stories of women professional accountants. Examining the personal narratives of career using Simone de Beauvoir feminist existentialist philosophy as a theoretical framework. Qualitative Research in Organizations and Management: An International Journal 4(1) 62-84. DOI 10.1108/17465640910951453

Young-Bruel, E (1982) Hannah Arendt: For the Love of the World. London \& New York: Yale University Press. 
${ }^{i}$ A fundamental disagreement emerged between Heidegger (1949) and Sartre regarding whether essence precedes existence. In Heidegger's view, who we are, Dasein, exists prior to our action in the world. Sartre vehemently disagreed on this point, arguing that it is how we act that defines who we are. For more on this, see McCann, C (1993) Four phenomenological philosophers: Husserl, Heidegger, Sartre, Merleau-Ponty. London \& New York: Routledge.

ii The term existential phenomenology is a common phrase used to distinguish the writings of Heidegger, Merleau-Ponty and Sartre from Husserl's transcendental approach. Heidegger is sometimes regarded as a hermeneutic phenomenologist. That said, this distinction are not always clear cut, and feminist phenomenologists often draw on more than one of these thinkers.

iiiParadoxically, it was not a feminist phenomenologist but a poststructuralist feminist who heralded the possibility of phenomenological feminism. In 1981, Judith Butler wrote a paper critiquing Merleau-Ponty's gender-neutral approach to embodiment. She urged feminist theorists to disrupt phenomenological readings by bringing a gendered theoretical perspective to major works. Those who followed Butler's call began by critiquing phenomenology for its lack of gendered perspective. See Butler, J Performative Acts and Gender Constitution: An Essay in Phenomenology and Feminist Theory. Theatre Journal. 40(4) (Dec., 1988): 519-531.

iv For an informative account of Beauvoir's turn toward feminism, as well as the antipathy of many feminists toward Beauvoir's work see Sonya Kruks (2012). Simone de Beauvoir and the Politics of Ambiguity. Oxford: Oxford University Press, pp. 45-50. 